\title{
Access to Academic Advising and Counselling of Pupils in Public Primary Schools in South East, Nigeria
}

\author{
Chinyelu Nwokolo, Ada Anyamene, Ngozi Oraegbunam, Ebele Anyachebelu, \\ Angelina Okoye, Amaka Obineli \\ Nnamdi Azikiwe University, Awka, Nigeria
}

\begin{abstract}
This study investigated the extent to which pupils have access to academic advising and counselling in South East public primary schools in Nigeria. The subjects for the study comprise 1768 counsellors drawn from all the Public Primary Schools in the five states that constituted the South East, Nigeria. The instrument was validated by two experts in Guidance and Counselling one from Nnamdi Azikiwe University, Awka and another one from Ebonyi State University, Abakiliki all in Nigeria. A test-retest method of reliability was used and a reliablity co-efficient of 0.83 was obtained. Mean scores and z- test statistics were used in data analysis. The result included that there is no significant impact of academic advising and counselling services from two out of five States studied. Based on the findings of the study, it was recommended that Government should provide counseling centers in all the Public Primary Schools to avail the Pupils of academic advising and counselling for better academic performance amongst others
\end{abstract}

\section{Introduction}

Academic advising and counselling is a programme that has been designed to help the individual attain a total development. If the individual is not properly guided he/she may not be able to take better decision later in life, hence the researchers deem it necessary to investigate the accessibility of academic advising and counselling among pupils in the public primary schools in South East, Nigeria. The primary level of education forms part of the foundation of every child's education; which if solidly made, the skills so acquired lasts for the child throughout life. Such skills in addition prepares and counselling given the indispensable roles it plays in the proper development of individuals becomes very much needed at the primary level of education. Its availability at this level is paramount considering the benefits it offers to recipients. Anagbogu and Mogbo [3] asserted that creating awareness of guidance and counselling services among primary school pupils would enable them to become focused quite early in their academic pursuit and be adequately directed to make future decisions.

Today many countries including Nigeria face significant new challenges in the primary schools' environment such as development in ICT, access to academic advising and counselling and the demands of global knowledge economy. These give rise to both opportunities and threats in primary school education, consequently the new challenges. However the goals of Primary education in Nigeria as stipulated in the National Policy on education, NPE 2004 include to:

- Inculcate permanent literacy and numeracy, and ability to communicate effectively;

- Lay sound basis for scientific and reflective thinking;

- Give citizenship education as a basis for effective participation in and contribution to the life of the society;

- Mould the character and develop; sound and morals in the child;

- Develop in the child the ability to adapt to the child's changing environment;

- Give the child opportunities for developing manipulative skills that will enable the child function effectively in the society within the limits of the child's capacity; and

- Provide the child with basic tools for further educational advancement, including 
preparation for trades and crafts in the locality.

Looking at the above goals, none can be achieved without proper academic advising and counselling. House and Martin [8] defined academic advising as a profession focused on offering constructive counselling and guidance to students in order to assist them in meeting academic goals. Also for Omeje [12] and Stone and Dahir [14] counselling is a service concerned with creating opportunities and awareness for personal/social, educational and vocational growth of the individual which can be used in national and international development. Marrying the two definitions above academic advising and counselling is ideally an implementation of a data - driven, evidence - based and comprehensive school counselling program that promotes and enhances pupils achievement, career and school readiness, personal and social competencies at the primary, post primary and tertiary levels (Dimmitt, Carey and Hatch [4] , HolcombMcCoy [6] and ASCA [1].

Moreso, academic advising and counselling offers assistance in evaluating skills and talents, advising pupils in the selection of course and academic programmes which seek to help pupils combine those abilities with his/her likes and dislikes (Portman [13], develop a plan of action in the pursuit of education goals that will produce the desired outcomes, and curb maladjustments found among students (Holcomb-McCoy and Chem-Hayes [7]. It is for the above reason that FRN [5] stipulated that counselling services should be made accessible to the pupils of primary schools in Nigeria. Unfortunately, like most aspects of the policy, the academic advising and counselling did not only run short of many needed ingredients but also has the problem of implementation. In spite of the fact that the curriculum conference of 1969 indicated that the absence of counselling was a missing link in our policy for which the national policy quickly addressed in 1977 and modified in 1981, 1998, and 2004, the policy according to Ifelunni [9] is still very defective. In the south east public primary schools of Nigeria Okeke and Okorie[11] asserted that lack of adequate functioning of the counselling centre where the academic advising and counseling takes place may be responsible for inappropriate decision and maladjustment behaviour of pupils and poor performance among others. Also Offor [10] observed that the academic advising and counseling centres in most of the Nigerian primary schools exists only on paper. The problem of this study is therefore to find out if the academic advising and counselling office actually exist and if it does, is it accessible to the pupils of public primary schools in the South East, Nigeria? The purpose of the study is to find out if pupils in south east public primary schools in Nigeria have access to academic advising and counselling.

The study is guided by one research question 1. To what extent do pupils of public primary schools in South East, Nigeria have access to academic advising and counselling?

Two null hypotheses were tested at the 0.05 level of significance, these are:

1. There is no significant difference between the mean scores of counsellors based on gender.

2. There is no significant difference between the mean scores of counsellors based on school location.

\section{Method}

The design of the study was survey. The study was carried out in the south east public primary schools of Nigeria. All the counsellors in all the public primary schools in the five states namely Anambra, Enugu, Imo, Abia and Ebonyi which make up the South East, Nigeria constituted the population. There was no sample, all the 1768 counsellors were used so it was a census survey. The instrument was a structured questionnaire developed by the researchers. The instrument was validated by 3 experts in guidance and counseling and measurement and evaluation. The instrument was analyzed using the Cronbach's Alpha procedure. The reliability analysis yielded Cronbach's Alpha value of 0.83.The instrument was therefore deaned reliable for the study. The researchers adopted a direct approach in the administration of the instrument to the respondents. By this method, copies of the instrument were taken to respondents' schools and administered personally with the help of 18 research assistants who were duly oriented. The direct approach facilitated instant collection. The data collected in respect of the research question was analyzed using mean while the hypothesis was tested using z-test statistics at 0.05 level of significance.

\section{Results}

The results of the study are presented below. 
Table 1. Respondents' mean scores for the extent of access to academic advising and counseling

\begin{tabular}{|l|l|l|}
\hline South East State & Counsellors No & Mean \\
\hline Anambra State & 572 & 3.10 \\
\hline Enugu State & 311 & 2.31 \\
\hline Imo State & 416 & 2.83 \\
\hline Abia State & 296 & 2.74 \\
\hline Ebonyi State & 173 & 2.25 \\
\hline
\end{tabular}

Table 1 shows that pupils from 3 public primary schools, have access to academic advising and counselling while pupils from 2 public primary schools do not have access to academic advising and counseling. From the data it shows that only some of the state schools have access to academic advising and counselling.

Table 2. z-test summary for significant difference of the mean scores of male and female students on access to academic advising counselling

\begin{tabular}{|l|l|l|l|l|l|}
\hline Variable & Mean & SD & Z-cal & $\begin{array}{l}\text { Z- } \\
\text { critical }\end{array}$ & P \\
\hline $\begin{array}{l}\text { Male } \\
\text { Counsellors }\end{array}$ & 2.10 & 1.32 & & & \\
\hline & & & 0.81 & 1.96 & 0.05 \\
\hline $\begin{array}{l}\text { Female } \\
\text { Counsellors }\end{array}$ & 2.20 & 1.14 & & & \\
\hline
\end{tabular}

Result in Table 2 indicate that the male counsellors obtained a mean of 2.1 with a standard deviation of 1.32 while the female obtained a mean of 2.20 with a standard deviation of 1.14 . It can be observed that $\mathrm{Z}$ value 0.81 at 0.05 level of significance is less than the table $\mathrm{z}$-value of 1.96, therefore the hypothesis is accepted indicating that there is no significant difference in the respondents mean scores due to gender.

Table 3. z-test summary for significant difference of the mean scores of Urban and Rural counsellors on access to academic advising and counselling

\begin{tabular}{|l|l|l|l|l|l|}
\hline Variable & Mean & SD & Z-cal & $\begin{array}{l}\text { Z- } \\
\text { critical }\end{array}$ & P \\
\hline $\begin{array}{l}\text { Urban } \\
\text { counsellors }\end{array}$ & 2.73 & 0.52 & & & \\
\hline & & & 2.06 & 1.96 & 0.05 \\
\hline $\begin{array}{l}\text { Rural } \\
\text { counselors }\end{array}$ & 1.74 & 0.96 & & & \\
\hline
\end{tabular}

Results in Table 3 reveal that at 5 percent level of significance, the calculated Z-value of 2.06 is more than the critical $\mathrm{Z}$-value of 1.96 , the hypothesis is rejected. Therefore the hypothesis is significant.

\section{Discussion}

Findings from the study revealed that out of all the 1,768 public primary school counsellors studied, 484 have never seen the structure of primary counselling centre how much more having access to the pupils from the centre to counsel in their areas of need. According to the study, they receive academic advising and counselling from Head teachers and Class teachers in the schools. This however confirms the assertion of Anagbogu and Mogbo[3] and Okeke and Okorie [11] who earlier asserted that lack of awareness of academic advising and counselling is responsible for inappropriate decision of pupils amongst other factors. The study further reveals no significant difference between the mean scores of counsellors due to gender. This may be due to the fact in the primary school system there is no gender discrimination. The implication is that pupils generally are young and are unable to take decisions on issues that concern them. Moreso their reasoning depends on their individual intelligence, environment and exposure in life. Furthermore in this era of ICT the pupils are exposed to the same experience irrespective of sex. The study also revealed a significant difference between the mean scores of pupils based on school type. The implication of the above result of study is that some of the public primary schools have already implemented while others are yet to implement theirs but surprising two states; Enugu and Ebonyi, have not started implementing the national policy on establishment of counselling centre as stipulated in (FRN [5]. This lack of implementation may be due to lack of relevant techniques and skills on how to convince the Government by the counselors of the states or lack of proper orientation on the usefulness of these counselling centres.

\section{Recommendation}

Based on the findings the following recommendations were made:

1. It is recommended that the government should set up new committee to see that the policy of establishing counselling centres in all public primary schools in Nigeria is implemented. 
2. The counselors in these primary schools should motivate the pupils using relevant skills and techniques.

3. The Guidance Counsellors in these schools should mount awareness campaign for the pupils to visit the counselling centres.

4. The professional counselors should introduce the counselling centres to pupils always especially during orientation of new pupils.

\section{Conclusion}

In conclusion, it was discovered that the public primary schools of two states in south east, Nigeria have no access to academic advising and counseling. Gender was not statistically found to be significant in terms of academic advising and counseling amongst pupils in south east public primary schools in Nigeria while location was found to be significant. Based on the above the implications of the findings and recommendations were proffered.

\section{References}

[1] American School Counselor Association. National model: A Framework for school counseling programs( $2^{\text {nd }} \quad$ ed.). ACA, Pennsylvania, 2005.

[2] Anagbogu M.A. Techniques for effective Implementation of Guidance and counseling in Nigerian schools. In Guidance and Counselling practice in primary schools. Globecommunication Onitsha, Anambra State. 2002.

[3] Anagbogu M.A. and Mogbo I. Creating awareness of Guidance and Counselling in the communities In Guidance and Counselling practice in primary schools. Globecommunication Onitsha, Anambra State. 2002.

[4] Dimuitt, C., Carey, J.C. and Hatch, T., Evidence based School counseling: making a difference with Data driven practices. Corwin Press, Thousand Oaks CA, 2007.

[5] Federal Republic of Nigeria.National Policy on Education. NERDC Press.Abuja,2004.

[6] Holcomb-McCoy, C. School counslleing to close the achievement gap. A social justice frame work for Success. Corwin Press, Thousand Oaks, CA, 2007.
[7] Holcomb-McCoy, C., and Chem-Hayes, S.F. Multiculturally competent school counselors: affirming diversity through challenging oppression. In B.T. Erford, (Ed).Transforming the school counseling profession ( $2^{\text {nd }}$ ed.), Pearson Merrill Prentice Hall, Upper Saddle River, NT, 2007, pp.98-120.

[8] House, R.M., and Martin, P.J. "Advocating Far better futures for all students: A new vision for school counselors" Education, Educational Media Corporation, Minneapolis, 1998, 284 291.

[9] Ifelunni, C. S. I., "Primary Education in Nigeria: Policy Provision and Implementation the missing link" unpublished. Paper presented at the national conference on Teacher Education, FCT, Asaba, 2005.

[10] Offor, T. C., Counseling access to primary Education. Totan Press, Owerri, 2008.

[11] Okeke, B. O. and Okorie, A. Fostering educational resilience and academic achievement in Nigeria. Fourth Dimension Publishers, Enugu, 2006.

[12] Omeje, J. C., Educational and occupational information in counseling, A fundamental approach. Dube Educational Books, Obollo, 2002.

[13] Portman, T. A. A., "Faces of the future: School counselors as Cultural mediators”, Journal of Counseling and Development, ACA, Pennsylvania, 2009, $21-27$.

[14] Stone, C.B. and Dahir, C.A school counselor Accountability a measure of student success ( $\left.2^{\text {nd }} E d.\right) 2007$. 